$$
\text { 木 }
$$

材中

通常の木材素材は, 周囲の条件之一定の関係を保ち ながら，種々の大きさをもち位置を占める木材（細胞 膜）実質，空吵掞よび水の 3 要素からできている.

木材実質は約50\%のセルロース，15２0\%のへミセ ルロース, 20〜30\%のリグニンの 3 主成分之, タンニ ン, 樹脂, 油脂, 色素などの従属成分とからできてい る. 主成分は高分子物質が多いが，炎の重合度は一定 しない，最も主要な成分であるセルロースは結晶領域 crystalline region, 非晶領域 amorphous region K 分けられ，前者の周围をとりまいて paracrystalline が存在する.

木材中の空隙は炉 (全乾) 乾状態においても存在す る先在的空隙と，膨潤剤によって新生される固溶体様 空間に大別できる，前者はさらに各種細胞の内こう， 樹脂道, 膜孔こうなどのマクロな空吵と, 膜孔膜小孔 および細胞膜中の微量の先在的空吵などのミクロな空 隙汾礼らるる。た，新生される固溶体様空間とは， 膨潤剂飞よって細胞膜中に形成される Stamm のいう contact area に関係する空間をさす。すなわち，乾 燥細胞膜内の solid-solid 界面が膨潤剤の吸着によっ $\tau$ solid-liguid-solid 界面 (Contact area) となり， 吸着質によって占められる新らしい空間をつくる。こ の空間をここで固溶体様空間とよぶ.

炉乾状態の木材に構造水と結合水の一部が存在する といわれている。構造水 water of constitution とは セルロースが熱崩壊をうけるような加熱下で，隣接 $\mathrm{OH}$ 基間の水素と $\mathrm{OH}$ 基で形成される水，したがって 加熱前は水ではなく実質の構成に与かっているもので ある、市た，種々の乾燥法で結合水 bound water の 下限を検討したStamm の結果によると，炉乾状態の 木材中に技艺らく $0.5 \%$ よりも少ない結合水が残存す る.したがって木材の炉乾状態とは厳密には絶対無水 の状態をさするのでない。

木材を大気中におくと，木材は大気の温湿度に応じ た平衡状態，すなわち大気の水蒸気圧と木材中の空吵 に存在する水蒸気の示す珐力（湿圧）とが等しくなる

* 本報を「木材と水(第1 報)」(The Relation between Wood and Water, I) とする. 原稿受理＼cjkstart昭和46年10月11日

** 正 会 員 京都大学農学部 京都市左京区北白川追分町

\section{の 水*}

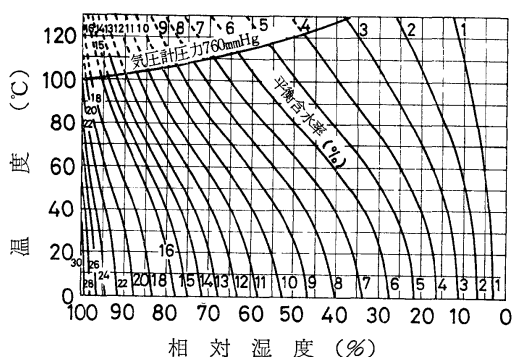

図 1 種々の温湿度下に扮ける木材の平衡含水率 - Sitka spruce, Kollmann ${ }^{9}$ による——

まで吸湿または放湿する。このようにして木材がおか れた空間の温湿度に平衡な状態にあるときの含水率を 平衡含水率 equilibrium moisture content とよぶ.こ の值は大気の条件が等しいとき，すべての樹種につい てほぼ等しく, Kollmann によってまとめられた Sitka spruce についてのこの值を示すと図1のと牱 りである。ここで注意を要するのは，木材を执いた空 間の温湿度が同じであっても, 平衡への到達が吸湿に よるか乾燥によるか炕って平衡含水率が異なること でこの現象を吸湿のヒステレシス hysteresis とよ ぶ.これについては後に述べる。また，特別な処理を ろけない木材でも，それを大気中で長期間放置すると き，吸湿性が低下しょり低い平衡含水率となる。何年 にもわたっての日々の乾湿の繰り返し，酸素扔よび紫 外線の作用などによる木材の枯し seasoning，あるい は何百年以上にもわたる常温物よび酸素などによる木 材の老化 ageing などはその例である.

木材細胞膜中で水がぞのよ5な機構で保有されるか については, 従来多くの研究者によって論議されてき た。これらの結果を総合すると，木材実質に水素結合 や van der Waals type の結合による物理吸着で保 有されている水一一結合水杰た汇吸着水 adsorptive water一一か細胞膜中の水の大部分を占め，ほかにミ クロな先在的空吵中での毛管凝縮水 capillary condensed water がある.

木材のマクロな先在的空吵には自由水 free water が保持される。

\section{1 結合水 (吸着水)}

結合水の増減俚木材の膨張収縮をひきおこし，物理 


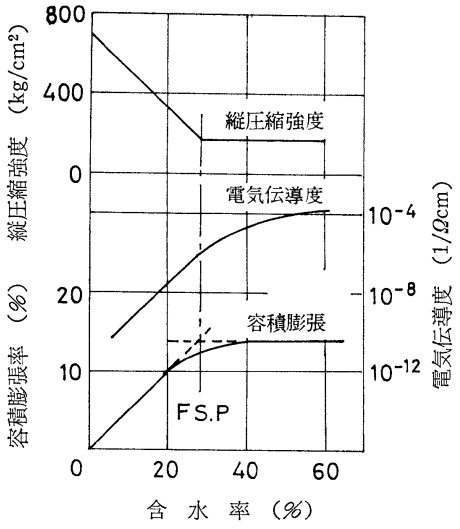

図 2 木材の含水率之物理的性質10)

的，力学的諸性質に関係する。図 2 亿例示するように， 乾燥状態から細胞膜中の水（ほとんど結合水）が増大 して繊維飽和点 (F.S.P.) に達するまで，木材の容積， 強度などは顕著に変化するが，これ以上の含水率範囲 では一定となる。電気扣よび熱に対する性質は F.S. P.を境として，その上下の含水率範囲で含水率によ る変化割合を異にする。

\section{$1 \cdot 1$ 吸着等温線}

Stamm は吸着等温線を図 3 に示す 5 型に分類して いる. Type 1 は飽和曲線型, Langmuir 吸着で, 全 ての固体への溶液からの吸着, 非膨潤無孔固体への臨 界温度以上のガスの吸着が，また化学収着もこれに属 する. Type 2 は明かな発熱をとるなう sigmoid 型 の吸着で，粉末状金属などの固体先在表面への臨界温 度以下のカスの吸着，木材のような膨潤性固体への水 の吸着などがこれに属する. Type 3 は発熱が微少で, 低相対湿度域での平衡吸着量が著しく小さく，相対湿 度の増大で急激に増大する type の吸着で，たとえば PEG，グリセリンなどへの水蒸気吸着がこれに属す る. Type 4 は type 2 の, type 5 は type 3 の特 殊のケースで, いずれも飽和蒸気圧よりもかなり低い 蒸気圧て吸着媒の微小な先在毛管に拈ける毛管凝縮を ともなう吸着系でみられる。

木材一水系の吸着等温線は図 4 亿示すよ5 亿典型的 な sigmoid 型 (type 2) である。これは木材の吸湿

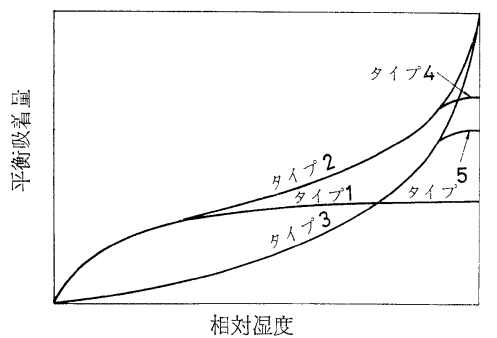

図 3 物理的吸着等温線のタイプ1)

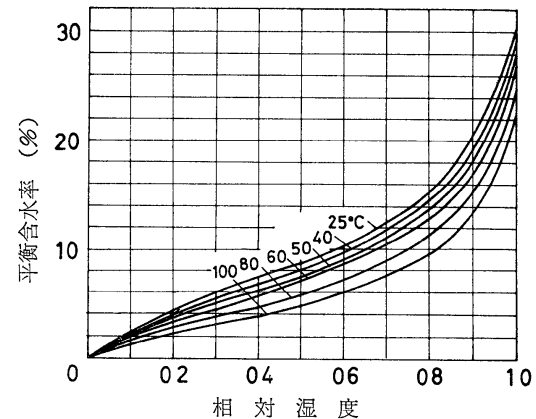

図4 種々の温度に批りる Sitka spruce の水の脱着 等温線—Stamm \& Harris11)

が単一の機構によるものでないことを意味する。まず， 相対湿度 0 から $20 \sim 25 \%$ 範囲では，全般的に平衡含 水率は急激に増大し, この範囲の等温線は Langmuir 型 (Stamm の type 1) の吸着を示す。これは吸着 質相互の分子間力よりもあきらかに大きい吸着媒先在 内部表面と吸着質分子間の結合力によって, 先在的な 内部表面に完全な単分子層吸着がなされることによる。 しかし木材の吸湿ではこの範囲の吸着に拈いても内部 表面の新生を考学なければならない。なぜならば，(1) 後述するように，木材一水系の微分湿潤熱は含水率 0 \%で高い值を示すが，含水率の増大で低下し 5 〜 $6 \%$ で $0 \%$ とさの $1 / 2 〜 1 / 3$ となる(図 6 参照)，(2)炉乾状 態の木材細胞膜はらっ素の吸着に対してほとんど無孔 とみなすことができ，ヒノキでは先在的空吵の容積率 がわずかに $0.32 \%$ ，比表面積は $1.08 \mathrm{~m}^{2} / \mathrm{g}$ である。 これらは Stone らの結果とも一致する。つぎに, 相対 湿度20〜25\%以上ではすで先在的内部表面がなく， 膨潤が先行する吸着だけとなり平衡含水率はほぼ直線 的に増大する。飽和状態に近い相対湿度（注ぼ90\%) に達すると, 主として膜孔膜小孔（先在的空隙）に和

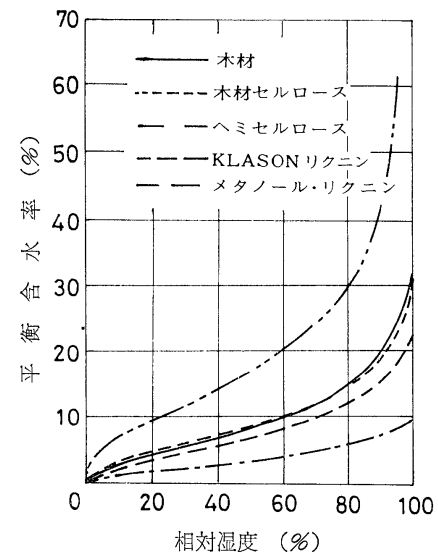

図 5 木忉蛙よびその構成成分の吸湿等温線—EUcalyptus regnans, $25^{\circ} \mathrm{C}$, Christensen ${ }^{14)}$ らによ る- 
ける毛管凝縮による水の保有が加わり，平衡含水率が 再び著しく増大する。

木材とその構成成分の吸着等温線を図 5 (Eucalyptus regnans) に示す。これらの結果から Christensen らは木材の吸湿に関する寄与率がセルロース 47 \%, ヘミセルロース $37 \%$, リグニン $16 \%$ としている.

\section{$1 \cdot 2$ 単分子層吸着水}

木材材質に直接関係する結合水が細胞膜中に保有さ れる機構は，炉乾状態から含水率約 $5 \%$ \% 湿度範囲では定説を得ている.Stamm はこの結合水 を単分子層吸着水 monomolecularly adsorbed water とよび，その上限含水率が各種セルロース材料で最低 值, cotton の $2.82 \%$, 最高值, cellophane の $5.87 \%$, 木材では sugar maple $4.25 \%$, Sitka spruce $5.16 \%$ であり，これらに対応する相対湿度は19〜23.5\%で あるとしている。

木材の親水性成分であるセルロース，へミセルロ一 ス，ある程度親水性であるリグニンなどの $-\mathrm{OH}$ 基, -O-基, $-\mathrm{COOH}$ 基，なかでも量的に多い $-\mathrm{OH}$ 基が木 材の親水性の主要な基因となる。乙かもこれらの基が 吸着点として働くことができるのは非晶領域に存在す るもので，セルロースの結晶領域では吸湿に関与しな いことがX線的研究によってしられている.

低含水率域で吸着点と水分子が水素結合によって結 合しているとの判断は熱力学的成果や赤外線分光法に よる結果にもとづいている. 図6は Sitka spruce に ついての微分湿潤熱と含水率の関係を示す．無限量の 木材から単位重量の結合水を離脱させるに要する熱量, いいかえると木材と水の結合エネルギは，図示のよ 5 に炉乾状態で最大 $\left(280 \mathrm{cal} / \mathrm{g}: \mathrm{H}_{2} \mathrm{O}\right)$ で, 含水率の 増加で急激に低下し，F.S.P.で 0 となることがわか る. 同様のことは Klinki pine についても認められ ている. 炉乾状態での微分湿潤熱は, cotton で 265〜 $330 \mathrm{cal} / \mathrm{g}$, vincose rayon で $270 \mathrm{cal} / \mathrm{g}^{8}$ で, これらは

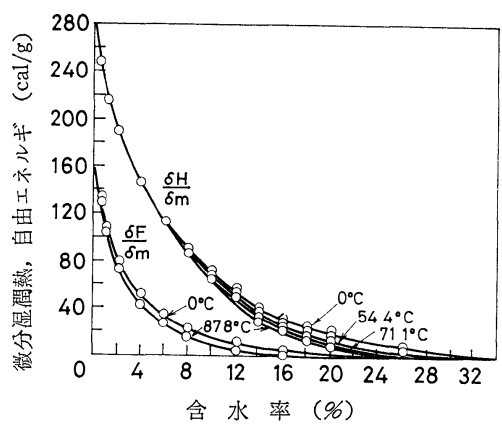

図 6 種々の温度に和沙る木材の微分湿潤熱 $\sigma H / \sigma m$, 自 由エネルギの変化 $\sigma F / \sigma m$ と含水率の関係16) 一 Sitka spruce. 脱着データで Clausis Clapeyron 式による計 算值一
それぞれ $6.0,4.9 \mathrm{kcal} / \mathrm{mol}: \mathrm{H}_{2} \mathrm{O}$ に相当する。 た木材では $5 \mathrm{kcal} / \mathrm{mol}: \mathrm{H}_{2} \mathrm{O}$ に相当する. これらの 值はいずれも水素結合の結合力の範囲 (5〜8 Kcal) $\mathrm{mol}: \mathrm{H}_{2} \mathrm{O}$ ) に含まれる.なお, 木材とその構成成分 の微分湿潤熱の比較を, Eucalyptus regnans につい て表 IV示す. 以上のことからこの範囲の結合水は吸 着媒の先在的内部表面に水素結合によって単分子層を 形成するるのであるとの定説になっている。乙かし， 既述のようにこの範囲の含水率増加による微分湿潤熱 の急激な低下 (図 6 ), 細胞膜の先在的空隙が微少な こと，执よび強い結合によって吸着された水の縮小が 考えられるにもかかわらず吸着に膨潤を伴うことから， 炉乾状態の木材に最初に吸着される水分核細胞膜中の わずかな活性基と水素結合するとともに，隣接 $\mathrm{OH}$ 基 間の結合をたって新らしい吸着点をつくり，したがっ て膨潤が先行して水の単分子層を形成することを含む と理解すべきであろう.な特, 隣接 $\mathrm{OH}$ 基間の結合が 水素結合であることは, 重水素置換法と赤外分光法を 併用した検討で裏付けられている。

表I 木材执よびその構成成分の炉乾状態に扔ける 微分湿潤熱—Eucalyptus regnans-

\begin{tabular}{|c|c|c|}
\hline 料 & 微分湿㠈熱 $\mathrm{cal} / \mathrm{g}$ & $\mathrm{H}_{2} \mathrm{O}$ \\
\hline 木 & 280 & \\
\hline ホロセルロース & 320 & \\
\hline セルロ & $270 \sim 350$ & \\
\hline ヘミセルロース & $200 \sim 250$ & \\
\hline リ グ $=$ ン & $150 \sim 200$ & \\
\hline
\end{tabular}

\section{$1 \cdot 3$ 多分子層吸着水}

細胞膜中の先在的内部表面が水で完全に飽和された 相対湿度20〜25\%以上での結合水の保有機構について は，多分子層吸着および単分子層吸着などの異なった 見解がある。

木材の吸湿について広く認められている多分子層吸 着の代表的な理論式である BET 式は

$$
-\frac{1}{m} \frac{x}{(1-x)}=\frac{1}{m_{0} C}+\frac{C-1}{m_{0} C} x
$$

$m$ : 相対湿度 $x$ に打ける平衡吸着量, $m_{0}$ : 吸着媒 表面が単分子層で被われたときの吸着量, $C$ : 結合 エネルギ $E_{1}, E_{L}$ を含む定数, $E_{1}$ : 吸着媒と吸着質 の結合エネルギ, $E_{L}$ : 吸着質の凝縮熱

吸着層の数を $n$ とし，多分子層吸着に関する式として，

$$
m=\frac{m_{0} C x}{(1-x)} \frac{1-(n+1) x^{n}+n x^{n+1}}{1+(C-1) x+C x^{n+1}}
$$

この式は $n=1$ のとき Langmuir 式に, $n=\infty$ のき 前記 BET の一般式に一致する.

Langmuir 式での多分子層吸着の包含をはかった 
BET 式は，その誘導の過程で膨潤を直接考慮してい ない。乙かし，細胞膜中に多分子層吸着の場となるほ ぞの先在的空吵をもたない木材の場合，この理論式の 物理的意義に，細胞膜中の新らしい空間の形成，すな わち膨潤を伴うとの理解をもたな゙ければならない。す なわち，単分子層の形成によって，これに隣接する非 晶部分で solid-solid 界面を破った単分子層の新らし い吸着表面が形成されるのと同様に，より高次の多分 子層吸着がなされるためには，まず既存の吸着層の結 合が隣接する多分子層または単分子層の形成によって 解離されなければならない。解離された表面により高 次の層の吸着がなされる。この結果新たに吸着された 水分量に相当する細胞膜の膨潤がみられることとなる. 一方, 吸着水の容積と木材の容積膨張率の関係につい て, Keylwerth の興味深い検討結果がある。この結 果を示す図 7 の縦軸は単位重量または容積の含有水分 に対応する木材の容積膨張量 $\mathrm{mm}^{3}$ を示し, この值が $10 \mathrm{~mm}^{3}$ であるとき吸着された水分容積と木材の容積 膨張量が等しい，同図から(1)強い結合力のはたらいて

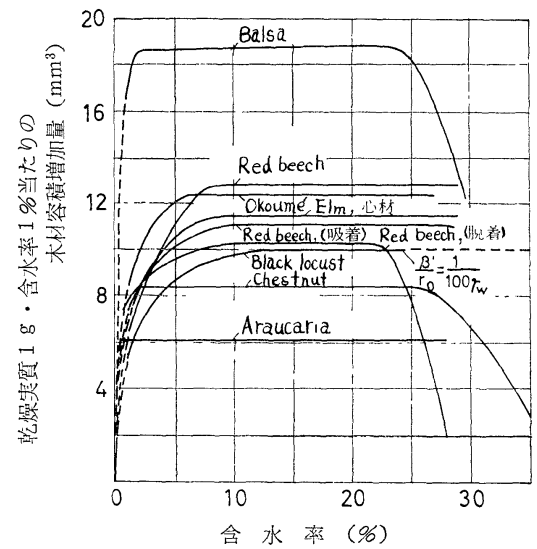

図 7 種々の樹種の比容積增加量と含水率 —Keylwerth20)による—

いるほぼ $5 \%$ 以下の低含水率域（単分子層吸着水）で は吸着された水の縮小によって基準值 $\left(10 \mathrm{~mm}^{3}\right)$ 以 下の值を示す， (2) Balsa 拉よび Araucaria 材を除い て, 多くの樹種では広い含水率域にわたって吸着され た水の容積がそのまま木材の容積膨張量となること が理解できる. 後者は細胞内こうなどの木材のマク口 な先在的空吵の大きさが膨潤のさいに変化せず，細胞 膜の膨張（吸着された水分量）が木材の容積膨張とな ることを意味する。

Stamm はこの範囲の結合水を多分子層吸着水 polymolecularly adsorbed water とょび, BET 理論に もとついて検討した結果，吙乾状態で比表面積が 0.2 $\mathrm{m}^{2} / \mathrm{g}$ 程度であった木材の吸湿に有効な contact area は, Sitka spruce で $254 \mathrm{~m}^{2} / \mathrm{g}$, sugar maple で 210 $\mathrm{m}^{2} / \mathrm{g}$, となり, いちじるしく増大し, 平均吸着分子 層数は Sitka spruce 6.4, sugar maple 7.4 であっ た。

なお，木材細胞膜の構造からみて，相対湿度20〜 25 \%以上で含有される水分が全て多分子買吸着水である と理解すべきでなく, 非晶領域に新たに形成される吸 着表面での単分子層吸着水をこの範囲に拈いても新た に含むである弓。このよ5に，木材水分の保有機構の らがいによる判然とした限界が，相対湿度または木材 の平衡含水率において存在せず，等しい条件下におい ても木材の吸湿に二つ以上の機構が与かり，また，一 つの存在状態（単分子層吸着水）から他の存在状態 (多分子層吸着水) への移行もなされる.

一方，単分子層吸着のすぐれた理論式は山田らによ って示されている。

$$
\frac{m}{m_{1}}=\frac{C x}{1+C x}\left\{1+\left(k^{\prime}+k^{\prime \prime}\right) \frac{x-x^{n}}{1-x}\right\}
$$

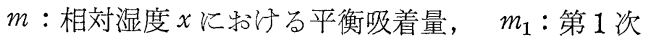
吸着点だけが飽和されたときの吸着量, $C: E_{1}, E_{L}$ を含む定数， $k^{\prime}$ : 吸着量一変形量に関する定数， $k^{\prime \prime}$

: 毛管凝縮に関する定数, $n$ : 吸着点の次数 山田らは BET 式が高相対湿度で実験值と一致しない こと, 式誘導の過程で膨潤を考慮していないことなど から疑問をもち，吸着によって順次内部表面を新生す る単分子層吸着理論を確立した。すなわち, 弾性膨潤 ゲルの吸湿に和いて，水分子は先在的内部表面の第 1 次吸着点に吸着されると同時に吸着媒分子間を弾性的 に拡げる。これによって隣接した第 2 次の内部表面を 新生する.このょうにして第 $n$ 次の吸着点まで内部表 面を搪げる。このさい第1次の吸着点の結合エネルギ $E_{1}$ は第 2 次〜第 $n$ 次の吸着点のそれよりも大きく, 後者を水の凝縮熱 $E_{L}$ に等しいとしている. また低含 水率で膨潤量が吸湿量に比例しないこと，次に述べる 高相対湿度域に括ける毛管凝縮水に対する補正を扣こ なっている。

\section{2 毛管凝縮水と繊維飽和点 (F.S.P.)}

\section{$2 \cdot 1$ 毛管凝縮水}

多孔体である木材の吸湿等温線が高相対湿度域で急 激に上昇する（図 4 参照）ことの原因として，木材中 に和ける水の毛管凝縮が考えられている.毛管内の液 体表面上の蒸気圧とメニスカスの曲率半径の関係は次 の Kelvin 式で示される.

$$
r=-\frac{2 \sigma M}{\rho R \operatorname{RIn} \frac{p_{r}}{p}}
$$

$r$ ：メニスカスの曲率半径, $\sigma, M, \rho$ : 液体の表 面張力, 分子量, 密度, $R$ : 気体定数, $T$ : 絶対温 度, $p_{r}$ : メニスカス上の蒸気圧, $p$ : 飽和蒸気圧 
（平らな水面上での蒸気圧）

表 II 種々の相刘蒸気圧のもとで疑縮水でみたされ る毛管の大きざ-Kelvin 式炕る計算値一

\begin{tabular}{c|c}
\hline 相 対湿度 & 毛管半径 $\mu$ \\
\hline 090 & 0010 \\
095 & 0.020 \\
097 & 0035 \\
098 & 0053 \\
099 & 0106 \\
0995 & 0210 \\
0999 & 1.060 \\
09999 & 1060 \\
\hline
\end{tabular}

すなわち，毛管の径が小さいほど，より低い相対湿度 で㠜縮する。この式で求められた毛管半径と凝縮水で 毛管が充される相対湿度との関係は表 II のと特りであ る.

一方, 木材細胞膜中の毛管は先在的空陵では膜孔膜 小孔と膜内非晶領域の微量のミクロな空吵であり, 吸 湿によって新生される空隙は既述の固溶体様空間であ る. 膜孔膜小孔の空隙の大きさは半径で $0.01 \mu \sim 1 \mu$ にわたり，最小值の場合，表飞示すように相対湿度 0.9 で毛管凝縮が発生することとなる。このことは平 均繊維長よりも厚い木材のクロス・セクションに括け る空気の透過性が，セクションの含水率がF.S.P. に 近くなるとき著しく低下することで裏付けられている。

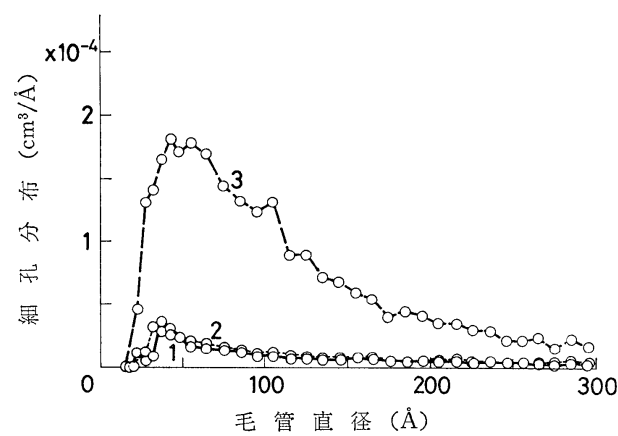

図 8 乾燥木材細胞膜中の細孔分布13)—七ノキ 木粉, 1 : 無処理試料, 2 : アル・ベン抽出処 理試料, 3 : 脱リグニン試料—

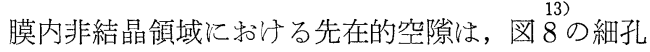

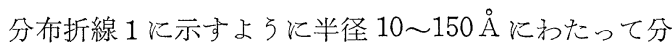
布するが，空吵容積は既述のようにわずかに $0.32 \%$ に すぎない。しかもこれらの毛管は壁面の実質伋着さ れた結合水によってせばめられ，毛管凝縮水の存在が 無視できる程度で两ろう，一方, 結合水によって形成 される細胞膜中の固溶体様空間は吸着された水によっ てみたされている。
したがって，木材細胞膜での水の毛管凝縮は主とし て膜孔膜小孔で, 相対湿度 $90 \%$ (平衡含水率 $20 \sim 27 \%$ ) 以上で生じるもの之結論できる。な拈，毛管凝縮水に 関連して次の 2 点をあげるべきであろう。

（1）細胞内こう，膜孔などのマクロな先在的空隙に 执いても，Kelvin 式にしたがって飽和蒸気圧が低下 する。（内こうの先端部を考虑するとき相封湿度 99.5 〜99. 99\%以上で凝縮がみられることとなる). したが って毛管凝縮の上限は木材が水で飽和されたときの含 水率となるが，木材中の空吵の分布が膜孔膜の小孔と 細胞内こうとの間で不連続なことから, 細胞膜が飽和 されたときの含水率 (F.S.P.) となる。

（2）相対湿度 $90 \%$ 以上でも，木材中に毛管凝縮水之 々も飞吸着水が新た㳭有される。このことはF.S.P. 近くまで湿潤熱が発生すること, 膨㵎がみられること 汇ょって裏付訂られる。

\section{$2 \cdot 2$ 緎維飽和点 (F.S.P.)}

全ての細胞膜が最大限度まで水を保有して膨張し， しかも木材のマクロな先在的空吵に水（自由水）をる たないときの木材含水率を瀻維飽和点 (F.S. P.) fiber saturation point とよぶ.したがって前項の記述から も理解できるょうに, F.S.P. とは相対湿度 $100 \%$ に 括计る木材の平衡含水率ではなく，100％近い高相対 湿度域に対応する吸湿等温線から外挿して兄られる值 であり，すべての木材を通じて含水率25３5\%，平均 28\%である。な和， fiber saturation poins の用語を はじめて用いたのは Tiemann (1906) である。

木材含水率と材質の関係を例示した図 2 飞示すょう 飞, F.S.P. 以上で木材材質が一定值を示すか, F.S. P.を境として含水率による材質の変化割合を異にす る.これは F.S.P. 以下の水（主として結合水）が 細胞膜実質によってその分子運動が制約されているの に対して，自由水はその移動や蒸発が実質によって拘 束されず自由に行動できる水であることによる. 自由 水の增減は木材重量の增減, 熱, 電気などに関する材 質に F.S.P. 以下とは異なる程度の影響を及洔すに とどまる。な特，自由水の上限含水率（木材の最大含 水率) は, 材の比重に関係する。

$$
U_{\max }=28+\frac{1.50-r_{0}}{1.50 r_{o}} \times 100=\frac{1.50-R}{1.50 R} \times 100 \%
$$

$U_{\max }$ : 最大含水率, $r_{0}$ : 炉乾比重, $R$ : 容積密度 $=$ (炉乾状態の重量) /(最大膨潤状態の容積)

木材中の水の存在状態を総括する见さきだち, 図 9 に示す Kollmann の結果が興味をひく、その吸着等 温線の理論的解析によると, 木材一水系の sigmoid 型 の吸着等温線は 3 種の compoment 江分けられる。す なわち，(1)真の吸着曲線（図 9 の $U_{1}$ ) で Langmuir 
式ないし Freundlich 式に適合する，(2)見かけの毛管 㠜縮水 $\left(U_{2}\right)$ で細胞膜中のミクロな空吵（本稿の固溶 体様空間) 飞保有される，(3)真の毛管凝縮水 $\left(U_{3}\right)$ で マクロな空隙（膜孔膜小孔）飞保有される。しかも， 既に述べたよ 5 に相対湿度または平衡含水率沈いて， 木材の水分保有機構の差による判然とした限界が存在 せず，等しい条件下に拈いても吸湿に二つ以上の機構 があずかり，それによって異なった機構による水があ らた保有されることがわかる。このことが木材拉よ び木質材料の吸湿性，含有水分之材質㐨よび加工性の 関係を複雑汇する。

本稿での木材中の存在状態を総括すると図10のとお りである。

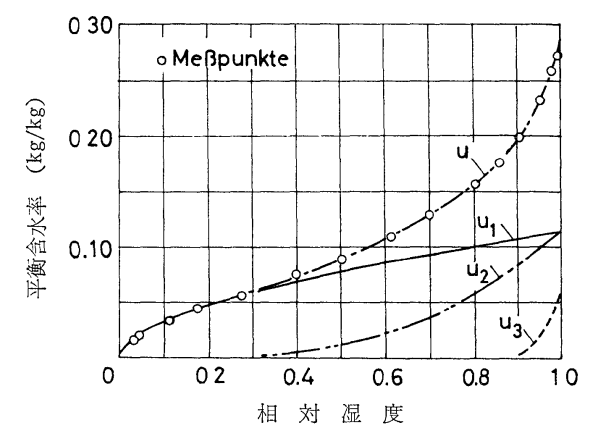

図 9 木材の吸湿等温線 24 —- Spruce, $20^{\circ} \mathrm{C}$ $u_{1}$ : 吸着水, $u_{2}$. 超顕微鏡的毛管の凝縮水, $u_{3}$ : 顕微鏡可視的毛管の凝縮水

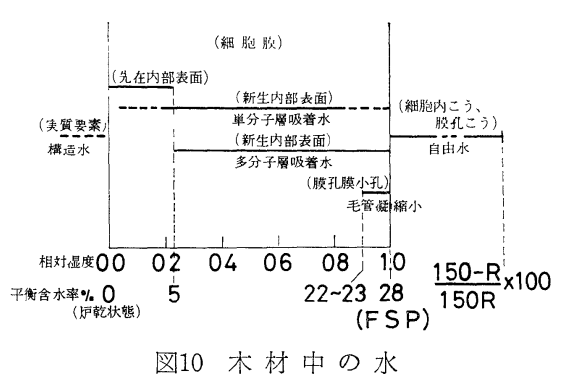

3 吸湿ヒステレシス

既に述べたところから木材の吸湿の特徴は，(1)吸着 等温線が sigmoid 型であり，木材の吸湿にはすくな くとも二つ以上の機構があずかる，(2)微分湿潤熱は炉 乾状態で $280 \mathrm{cal} / \mathrm{g}$ で西り, 高含水率になる注ど急激 に低下し，F.S.P.では 0 となる，(3)膨潤系であって， 水分子の吸着に先行して非晶領域に新らしい吸着表面 を形成し，固溶体様空間を拡大する，さらに(4)ヒステ レシス現象を示す.

\section{$3 \cdot 1$ ヒステレシス現象}

木材やセルロースなどの膨潤性高分子は, 同一試料 であってもある相対湿度に扮汀る平衡含水率が, 上り 低い含水率から吸湿によって到達したか, より高い含

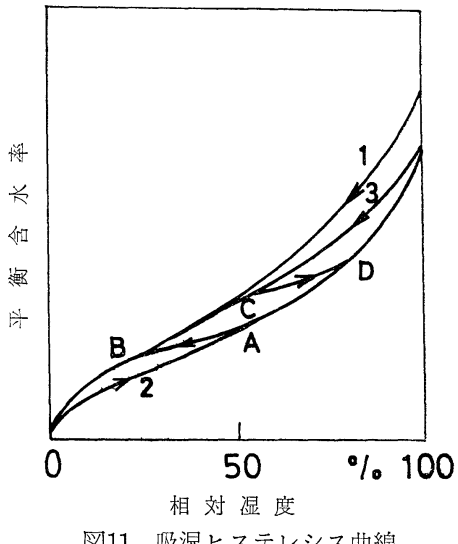

図11 吸湿ヒステレシス曲線

水率からの乾燥によって到達したかで異なり，常に乾 燥に上る平衡含水率が吸湿に上るそれよりも高い。こ の現象を吸湿に护るとステレンスとよぶ。

いま，生材を段階的に低い相対湿度に平衡させると， 脱着は図11曲線 1 の等温線を経て進行する。つぎに含 水率 $0 \%$ に達したこの木材を段階的に高い相対湿度に 平衡させると, 吸着は曲線 2 の等温線を経て進行し F.S.P. (㛜密にはこの点を外挿して決定することは 既述のと和り）飞達する，曲線 2 を標凖吸着等温線と よぶ。このようにして吸湿した木材を再び段階的に乾 燥すると, 脱着は曲線 3 (標隼脱着等温線) の過程を 経る. 生材か) らの最初の脱着等温線は標準脱着等温線 と, Stammによると相対湿度 $60 \rightarrow 0 \%$ 亿わたって一致 する。したがって相対湿度 $100 \rightarrow 60 \%$ の最初の脱着等 温線は全く不可逆であり, この理由後述するとヒス テレシスの原因と考兄られる活性 $-\mathrm{OH}$ 基の有効性の

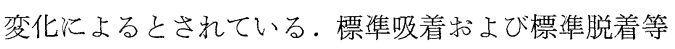
温線の full cycle にわたっての過程は可逆的であり, 曲線 2,3 で形づくられるヒステレシス・ループ上を 経過する。また，いま吸湿によって平衡している木材 を図11のA点で脱着させると, 曲線 2 から曲線 3 亿 わたる曲線 $\mathrm{AB}$ の過程をとる. 脱着平衡の木材を $\mathrm{C}$ 点 て吸着させると同様汇曲線 $\mathrm{CD}$ の過程を経る.このよ う部分的な相対湿度範囲での吸脱着によってもルー プ内で小ループ上を進行する. 以上の上らに木材の吸 湿ヒステレシスは全相対湿度範囲（木材の感湿範囲） そわたってみられる。

温度のコントロールがすぐれた実験で得られたヒス テレシス・ループについて, 等しい相対湿度下での脱着 平衡含水率飞対する吸着平衡含水率の比は, リグニン では相対湿度の増大で直線的に増大する傾向があるが, セルロース材料ではほぼ一定とみなしうる。 Stamm によると white spruce, Klinki pine, Eucalyptus regnans, western hemlock の 4 樹種の木材に括ける この比の平均は $0.82 \pm 0.01,23$, 樹種のパルプ, ホ 


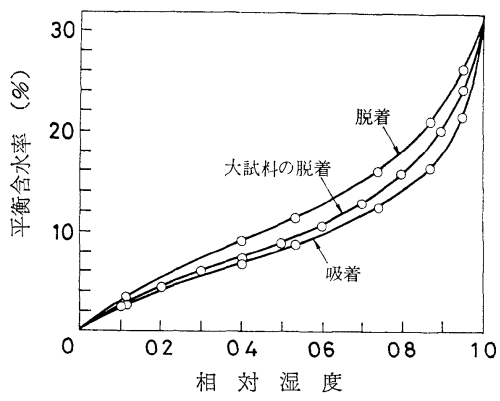

図12 木材の水蒸気吸脱着等温線 ${ }^{16)}$ — spruce, $25^{\circ} \mathrm{C}$

ロセルロースで $0.86 \pm 0.02$ である。

木材の吸脱着が真空系でなされるか，空気の存在下 でなされるかはとステレシスに無関係であるが，試料 の大きさは関係する．温湿度のコントロールが正確で あっても，大きい試料で求めた脱着等温線は図12に示 すように，小さい試料で求めたヒステレシス・ループ の中に入る.この等温線を osillating desorption と よぶ。これは大きい試料中の湿圧が充分コントロール されないため, 脱着と吸着が同時に発生する,すなわ ち, 試料の中心部で脱着した水分が再び表層近くで吸 着されることによる。

\section{$3 \cdot 2$ ヒステレシスの原因}

たと㓪ばシリカ・ゲルのような多量の微細な毛管を もつ非膨潤剛性吸着媒の場合, 吸湿ヒステレシスは毛 管凝縮で説明される。すなわら, 管壁面に和ける水の 接触角は吸着過程（前進接触角に相当）分脱着過程 （後退接触角に相当）よりも大きく, メニスカスの曲 率半径も吸着過程が大きい。そこで等しい平衡含水率 に対応する毛管中の飽和蒸気圧は, 既述の Kelvin 式 で明かなように吸着過程の方が大である。このような 吸湿ヒステレシスの説明は, F.S.P. 以下の含有水分 が，大部分吸着水である木材の場合とヒステレシスの 原因とはならない。

木材，セルロースなどの膨潤吸着媒においては，七 ルロースの活性 - $\mathrm{OH}$ 基の有効性が吸脱着過程で異な ることから説明される。すなわら，吸着表面の新生の 考え方を最初に明かにしたUrquhart ら注, 最初の水 中浸漬状態では大部分の - $\mathrm{OH}$ 基は水で飽和されてい る。この木材を乾燥すると飽和していた $-\mathrm{OH}$ 基のあ る数は水を失って活性となり，これらが相互にひきあ って結合し，木材は収縮する，再び吸湿するとき，相 互にみたしあっていた - $\mathrm{OH}$ 基のある部分が水に対し て活性とならない。このように高分子であるセルロー ス分子のだ性によって内部表面の出現消滅が可逆的に 行なわれない結果, 活性 $-\mathrm{OH}$ 基の有効性が吸脱着に よって異なる。この考光方のより理論的な説明は Smith その他によってなされているが，次のように
説明することができよう、膨潤性吸着媒である木材へ の水の吸脱着には, 細胞膜非晶領域に和けるセルロー スその他の分子の再配列，変形を伴5。いま，七ル口 一スだけに注目すると，吸湿にさいして非晶領域にお 壮る分子間隔の拡大, 分子の変形が必要であり, これ はセルロースの分子運動によってなされる．また，脱 着にさいして水分子がセルロースの - $\mathrm{OH}$ 基または先 に吸着されている水分子から離脱するとき，できた空 席は - $\mathrm{OH}$ 基相互または吸着されている隣接水分子相 互の結合によって陷没する。この場合もまた分子間隔 の縮小, 分子の変形を伴 万。完全な弾性体でない七ル ロース分子の変形は膨潤圧に対して一部永久変形とな り，脱着過程の吸着水の保有に対してプラスにはたら $<$.

\section{参 考 文 献}

1) Stamm, A. J., Wood and Cellulose Science, Ronald, New York, p. 134 (1964).

2) Stamm, A. J., rbid., p. 142 (1964).

3) Stamm, A. J., ıbrd., p. 144 (1964).

4) Stamm, A. J., ibid., p. 146 (1964).

5) Stamm, A. J., rbrd., p. 149 (1964).

6) Stamm, A J., ibid., p 162 (1964).

7) Stamm, A. J., ıbrd., p. 192 (1964).

8) Stamm, A. J., ibrd., p. 210 (1964).

9) Kollmann, F., Technologie des Holzes und der Holzwerkstoffe, Erster Bd., Springer, Berlın., s. 387 (1951).

10）梶田 茂編，木材工学，p 88 (1961) 養賢堂

11) Kollmann, F., and W.A. Côté, Principles of Wood Science and Technology, I Solid Wood, Springer, Berlin., p. 189 (1968).

12) Stone, J.E, A M. Scallan, and G. M. A. Aberson, Pulp Pap. Mag. Can., 67, 263 (1966).

13）大沢純二, 中戸莞二, 日本木材学会大会研究発表要旨, p. 15 (1971).

14) Christensen, G. N., and K. E. Kelsey, Aust. J. Appl. Sci., 9, 265 (1958).

15) Christensen, G. N., and K. E. Kelsey, Holz als R.u. W. 17, 189 (1959).

16) Stamm, A. J , and W. K. Loughborough, J. Phys. Chem., 39, 121 (1935).

17) Kelsey, K. E., and L. N. Clarke, Aust. J. Appl. Sc1., 7, 160 (1956).

18）谷口 高喿, 原田 浩, 中戸莞二, 木材学会誌, 12, 215 (1966).

19) Brunauer, S., P. H. Emmett, and E. Teller, J. Am. Chem. Soc, 60, 309 (1938).

20) Keylwerth, R., Holz als R.u.W., 20, 252 (1962).

21) 山田 正, 梶田 茂, 科学, 23, 318 (1953).

22) Stamm, A. J., Physics, 6, 334 (1935).

23) Tiemann, H. D., U.S. Dept. Agr. Fore. Serv. Bull., No. 70 (1906).

24) Kollmann, F., Fors. Geb. Ingenieurwe. 29, 461 (1963).

25) Smith, S. F., J. Am. Chem. Soc., 69, 646 (1947). 